\title{
HCV Extrahepatic Manifestations
}

\author{
Lucija Kuna ${ }^{1}$, Jelena Jakab ${ }^{2,3}$, Robert Smolic ${ }^{2,4}$, George Y Wu ${ }^{5}$ and Martina Smolic*1,4
}

${ }^{1}$ Department of Pharmacology and Biochemistry, Faculty of Dental Medicine and Health, J. J. Strossmayer University of Osijek, Osijek, Croatia; ${ }^{2}$ Department of Pathophysiology and Physiology with Immunology, Faculty of Dental Medicine and Health, J. J. Strossmayer University of Osijek, Osijek, Croatia; ${ }^{3}$ Department of Internal Medicine, Faculty of Medicine, J. J. Strossmayer University of Osijek, Osijek, Croatia; ${ }^{4}$ Department of Pharmacology, Faculty of Medicine, J. J. Strossmayer University of Osijek, Osijek, Croatia; ${ }^{5}$ Department of Medicine, Division of Gastroenterology-Hepatology, University of Connecticut Health Center, Farmington, CT, USA

\begin{abstract}
Hepatitis $\mathrm{C}$ virus (HCV) has been shown to affect many tissues other than liver. However, of the many extrahepatic manifestations (EMs) that have been associated with $\mathrm{HCV}$, including cryoglobulinemia, lymphoma, insulin resistance, type 2 diabetes and neurological disorders, only a few have been shown to be directly related to HCV infection of extrahepatic tissues. HCV-triggered immune-mediated mechanisms account for most of the EMs. It is estimated that up to $74 \%$ of patients with chronic hepatitis $C$ can develop at least one EM. All HCV patients with EMs should be considered for antiviral therapy, although not all will resolve with sustained virological response.
\end{abstract}

Citation of this article: Kuna L, Jakab J, Smolic R, Wu GY, Smolic M. HCV extrahepatic manifestations. J Clin Transl Hepatol 2019;7(2):172-182. doi: 10.14218/JCTH.2018.00049.

\section{Introduction}

Approximately $130-170$ million people, or $3 \%$ of the world's population, are chronically infected with the hepatitis $C$ virus $(\mathrm{HCV})$. It is a major public health problem, with an estimated 3-4 million people infected each year worldwide. In the USA, chronic hepatitis $\mathrm{C}(\mathrm{CHC})$ is one of the most significant causes of liver-related death and the most common indication for liver transplantation. ${ }^{1}$ Recently, the Centers for Disease

Keywords: Hepatitis C virus; Hepatic stellate cells; B cell lymphomas; pancreatic B cell; TGF- $\beta$-dependent signaling pathway; Extrahepatic manifestations; Direct-acting antivirals.

Abbreviations: $\mathrm{CD}$, cluster of differentiation; $\mathrm{CHC}$, chronic hepatitis C; DAA, direct-acting antiviral agent; DM, diabetes mellitus; EMs, extrahepatic manifestations; ERK, extracellular-signal kinase; HBV, hepatitis B virus; HCV, hepatitis C virus; HOMA-IR, homeostasis model for assessment of insulin resistance; HRQOL, health-related quality of life; IFN, interferon; IL, interleukin; IPF, idiopathic pulmonary fibrosis; IR, insulin resistance; $L P$, lichen planus; MC, mixed cryoglobulinemia; MHC, major histocompatibility complex; MIN6, mouse insulinoma; MPGN, type I membranoproliferative glomerulonephritis; NHANES, National Health and Nutrition Examination Survey; NHL, non-Hodgkin's lymphoma; NS, nonstructural; OLP, oral lichen planus; PCT, porphyria cutanea tarda; RA, rheumatoid arthritis; SOF, sofosbuvir; SS, Sjögren syndrome; SVR, sustained virologic response; T2DM, type 2 diabetes mellitus; TGF- $\beta$, transforming growth factor-beta; TNF- $\alpha$, tumor necrosis factor-alpha.

Received: 2 September 2018; Revised: 21 February 2019; Accepted: 17 March 2019

*Correspondence to: Martina Smolic, Department of Pharmacology, J. J. Strossmayer University of Osijek Faculty of Medicine Osijek, J. Huttlera 4, Osijek 31000, Croatia. Tel: + 385-31-512-800, Fax: +385-31-512-833, E-mail: martina. smolic@mefos.hr
Control and Prevention reported about 30,500 new cases of $\mathrm{HCV}$ in the USA, and estimated the number of chronic cases to be 2.7-3.9 million. ${ }^{2}$ It should be emphasized that every year more than 350,000 patients die from HCV-related liver diseases, and mortality rates in HCV-infected patients are three times higher than those in the general population.

It is known that $\mathrm{CHC}$ can lead to cirrhosis and hepatocellular carcinoma. The main site of HCV replication is in hepatocytes, which explains the significant liver damage that it causes. However, it is well known that the virus is not hepatotoxic, and the majority of the injury in the liver is caused by a cell-mediated immune reaction against infected liver cells. Similarly, immune abnormalities resulting in autoimmunity may be involved in the development of extrahepatic manifestations (EMs) (Fig. 1). EMs of CHC can be classified by the affected organ, system, or pathological mechanism. However, the strength of accessible evidence linking them to $\mathrm{CHC}$ varies. ${ }^{3}$ The clinical presentation of patients with $\mathrm{CHC}$ range from subclinical cases to very serious immunological diseases. Indeed, sometimes, autoimmune manifestations linked to $\mathrm{HCV}$ infection lead to the diagnosis of $\mathrm{HCV}$ infection. 4

This review aims to outline EMs, discuss strategies for early diagnosis and discuss the evidence supporting proposed mechanisms of development of autoimmune and lymphoproliferative conditions associated with HCV infection.

\section{Cryoglobulinemia and immune complex disease}

Cryoglobulins are immunoglobulins that often produce organ damage through either a hyperviscosity syndrome or immunemediated mechanism. ${ }^{5}$ Although cryoglobulinemia can be caused by many infections and disorders, it is most frequently described among $\mathrm{HCV}$ patients. In two studies, $36-54 \%$ of HCV-infected patients had detectable cryoglobulins and $25 \%$ displayed clinical symptoms related to cryoglobulinemia. ${ }^{6,7}$

Depending on the clonality and type of immunoglobulins, there are three basic types of cryoglobulinemias. During chronic HCV infection, cryoglobulins are immunochemically characterized as type II or type III cryoglobulins, a mixture of monoclonal IgM with polyclonal IgM and IgG immunoglobulins. ${ }^{8}$ The primary mechanism of injury in type II cryoglobulinemia is a vasculitis triggered by immune complex deposition. Although mixed cryoglobulins are found in between $40 \%$ and $60 \%$ of HCV-infected patients, overt cryoglobulinemic vasculitis is only observed in around $10 \%$ of those patients. ${ }^{5}$ The main clinical manifestations include cutaneous vasculitis with 


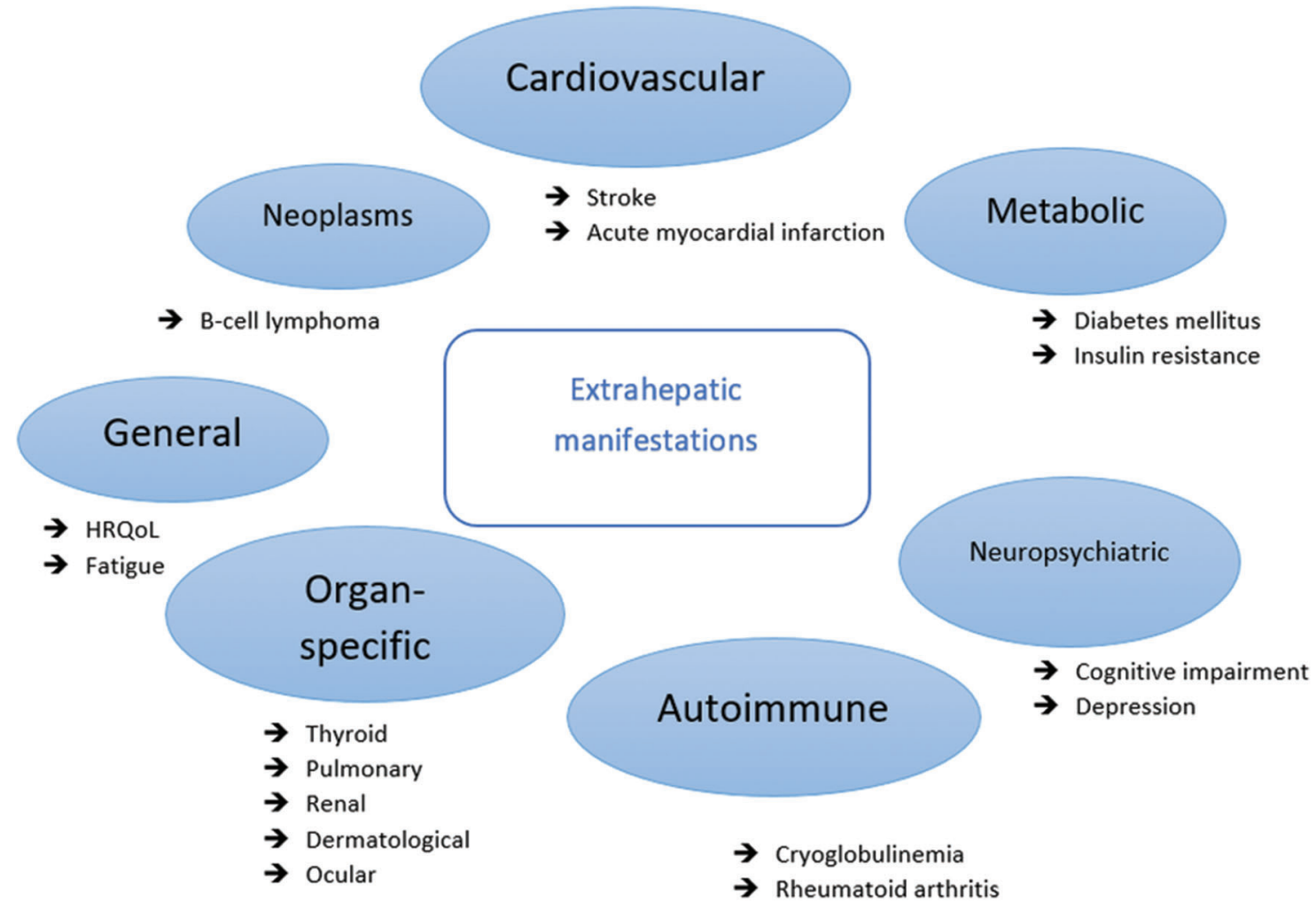

Fig. 1. Extrahepatic manifestations associated with chronic hepatitis $C$ virus infection.

palpable purpura (18-33\%), arthralgia-myalgia (35-54\%), neuropathy $(11-30 \%)$, and renal complications, such as glomerulonephritis (27\%). ${ }^{9-11}$

Sene et al. ${ }^{8}$ concluded that cryoglobulinemic vasculitis was associated with older age, longer duration of infection, mixed cryoglobulinemia (MC) type II, and higher mixed cryoglobulins' serum levels. In a recent retrospective Italian study on 231 patients with MC, HCV infection was positive in 155 $(92 \%)$, and the leading causes of death were associated with vasculitis $(46 \%)$, cancer or hemopathy $(23 \%)$, and liver disease $(13 \%) .{ }^{12}$ Increased mortality in patients with $\mathrm{MC}$ is connected with the presence of renal, intestinal and liver involvement, cardiovascular disease, infection, and lymphoma. ${ }^{13}$

Some studies have demonstrated the presence of $\mathrm{HCV}$ RNA negative strand in B-cells of patients that are chronically infected with HCV. Expression of the HCV-encoding nonstructural (NS) proteins NS3 and NS5 in peripheral blood mononuclear cells indicates that HCV not only replicates but also generates HCV proteins. ${ }^{14,15}$ While the cluster of differentiation (CD) 81 protein, which is expressed in B-cells, has been shown to be an entry receptor for $\mathrm{HCV}$, not all HCV strains are lymphotropic. It has been recently shown that HCV tissue tropism is genetically determined by the presence of viral proteins and the $5^{\prime}$-untranslated region sequences. Additionally, some studies have demonstrated the co-stimulatory receptor CD86 interferes with HCV lymphotropism involving memory B-cells. Moreover, binding of CD86 to HCV indicates the inhibition of memory B-cell function and increases the differentiation of memory B-cells in IgM-secreting plasmablasts. ${ }^{16,17}$
Furthermore, MC is associated with HCV in up to $90 \%$ of cases that are characterized by a monoclonal IgM with or without evident cryoglobulinemia-associated vasculitis. ${ }^{5}$ Moreover, approximately $10 \%$ of patients with MC have associated Iymphoproliferative disorders, and cryoglobulinemia carriers show a 35-times increased risk of development of non-Hodgkin's lymphoma (NHL). It has been shown that $\mathrm{CM}$ is characterized as a clinically benign pre-lymphomatous disease in which liver $\mathrm{B}$-cell clones resemble a low-grade NHL. ${ }^{17,18}$ On the other hand, in MC patients, expansion of selective $\mathrm{VH} 1-69+$ expressing memory $\mathrm{B}$-cells demonstrated that B-cells of HCV-associated MC are highly restricted. ${ }^{17,19}$

\section{B-cell lymphoproliferative diseases}

HCV has also been shown to be a lymphotropic virus ${ }^{20}$ and associated with several lymphoproliferative disorders, including monoclonal gammopathies in addition to $\mathrm{MC}$ and B-cell NHL. ${ }^{21}$ This association was reported in one meta-analysis of epidemiological studies, with HCV prevalence of $17 \%$ in B-cell NHL patients compared to $1.5 \%$ in healthy controls. ${ }^{22}$ Diffuse large B-cell NHL and marginal zone lymphoma are most frequently associated with HCV. Patients positive for anti-HCV antigen had a 2.5-fold increased risk of $\mathrm{NHL}$ versus controls, which doubled after adjusting for sex and age, regardless of primary site of presentation (nodal or extranodal). ${ }^{18}$

$\mathrm{HCV}$ infection of lymphocytes could play a direct role in cellular transformation, specifically in de novo large B-cell lymphoma. ${ }^{17} \mathrm{HCV}$ infection of two B-cell lines produced mutations in tumor suppressor and proto-oncogenes which 
were identified in HCV-associated B-cell lymphomas. ${ }^{23}$ Over the two last decades, two particular although not mutually exclusive models of infection-driven transformation have appeared. Direct lymphocyte transformation by lymphotropic transforming viruses (Epstein-Barr virus, human herpesvirus 8 , and human T-lymphotropic virus type 1 ) expressing viral oncogenes has been reported. However, a model of lymphocyte transformation finally leading to clonal expansion as an indirect mechanism of pathogenesis has been proposed. Mucosa-associated lymphoid tissue lymphoma must be ruled out. ${ }^{24}$

Sustained stimulation of lymphocyte receptors by viral antigens, viral replication in B-cells, and damage of B-cells have been proposed as mechanisms of pathogenesis. ${ }^{25}$ Findings from numerous studies support a significant role for HCV envelope glycoprotein E2 in indirect transformation. It has been shown that E2 binding to its receptor on B-cells (i.e. CD81) facilitates the assembly of the CD81/CD19/CD21 costimulatory unity. ${ }^{17}$ Nevertheless, HCV may attach concurrently to CD81 and a specific B-cell receptor on B-cells to trigger B-cell activation and proliferation. However, the E2CD81 complex displays a significant role in activating B-cells by decreasing their threshold of activation.

Chronic viral antigen stimulation may represent an important role in aberrant B-cell proliferation. ${ }^{26}$ Hence, expression of HCV viral proteins in B-cells of HCV-infected patients upregulates $B$-cell receptor signaling. Pro-inflammatory cytokines, such as the interleukins (ILs) IL-6, IL-17 and IL-10, and transforming growth factor-beta (commonly referred to as TGF- $\beta$ ) have also been reported to contribute to aberrant B-cell proliferation. ${ }^{27}$

\section{Diabetes and insulin resistance (IR)}

Several clinical studies have suggested an association between chronic HCV infection, IR and diabetes mellitus (DM) by demonstrating that patients with $\mathrm{CHC}$ have an increased risk for developing DM compared with uninfected individuals. ${ }^{28}$ The epidemiological observations found that type 2 diabetes mellitus (T2DM) developed in 14.5-33\% of patients with $\mathrm{CHC} .{ }^{29,30}$ The broad range of these findings may be the result of various factors, including age, ethnicity, body mass index, the prevalence of diabetes, viral load, and HCV genotype.

Antonelli et al. ${ }^{31}$ reported that the prevalence of T2DM was higher in patients with HCV-related cirrhosis than in those with cirrhosis resulting from other liver diseases. In addition, White et al. ${ }^{32}$ showed that $\mathrm{CHC}$ was associated with an increased risk of T2DM in comparison to uninfected and hepatitis $B$ virus (HBV)-infected controls. Data from the National Health and Nutrition Examination Survey (commonly known as NHANES) database in the early 1990s showed an independent association of IR and DM with HCV infection. Later NHANES studies failed to confirm these associations, probably due to the increase of other risks for DM, including a rapid increase in the prevalence of obesity. ${ }^{33}$

However, many other studies have shown a causal relationship between HCV infection and IR. ${ }^{34}$ For instance, the homeostasis model for assessment of insulin resistance (commonly referred to as HOMA-IR) showed that HCVinfected patients had significantly higher levels of IR compared to HBV-infected patients matched for body mass index, waist circumference, age, and gender. ${ }^{35,36}$ In addition, a large longitudinal prospective cohort study of Taiwanese patients found that $\mathrm{CHC}$ was an independent predictor of diabetes, especially for anti-HBV-positive, overweight, younger people. ${ }^{28} \mathrm{HCV}$-associated IR correlated with poor outcomes by accelerating the progression of hepatic fibrosis and the development of hepatocellular carcinoma, in addition to reducing sustained virologic response (SVR) rates. ${ }^{37}$

Genetic and dietary factors influence the development of T2DM. However, less is known about the role of some environmental factors, such as viral infections. Recently, some studies have shown the possible effect of HCV infection on the fate of mouse insulinoma 6 (commonly known as MIN6) cells, which is a mouse insulin-producing pancreatic beta cell line used broadly for diabetes studies. The findings demonstrated that HCV represents an independent risk factor for physiologic control of beta cell death in the pathogenesis of diabetes development. As shown in some studies, the presence of isolated virus was required to induce cell death $(62.1+2.01 \%)$ compared with the virus-free culture supernatants that did not result in beta cell failure $(18.9+0.28 \%)$. Analogous results were achieved with CON1 culture medium and deactivated $\mathrm{HCV}$, in that HCV inhibited pancreatic beta cell proliferation by directly inducing the death of MIN6 cells. ${ }^{38}$ Furthermore, various experiments have demonstrated that IR precedes the development of hyperglycemia in patients that may develop T2DM. T2DM only develops in insulin-resistant people presenting the beginning of beta cell dysfunction. 39,40

The notion of insufficient beta cell mass as a significant factor in the pathogenesis of T2DM has been broadly acknowledged. Beta cell mass plays an important role in determining the amount of insulin that is secreted to sustain the body's glucose levels within a tight range. Acute insulin response is subnormal in patients with HCV infection. However, it is uncertain whether IR alone induces diabetes without underlying deterioration of beta cells. On the other hand, potential effects of the virus on beta cells are not known yet, and there is no in vitro model to examine the hypothesis that HCV infection is directly related to damage of human beta islet cells.

\section{Cardiovascular and cerebrovascular disease}

$\mathrm{HCV}$ infection is a proven independent risk factor for the development of cardiovascular disorders and higher cardiovascular mortality, which directly impacts the prognosis of the patient. ${ }^{41}$ Despite having a more favorable lipid profile than healthy controls (uninfected individuals), ${ }^{42}$ patients with $\mathrm{CHC}$ have shown an increased risk of cardiovascular disorders. ${ }^{43}$ In one Taiwanese study, patients with $\mathrm{CHC}$ had an almost 1.5fold higher risk of developing peripheral artery disease than uninfected individuals, ${ }^{44}$ and this number increased in patients with increasing age and comorbidities.

The HCV viral load was independently associated with early, asymptomatic carotid atherosclerosis, having higher risk of peripheral artery disease. ${ }^{45}$ Consistent with this finding, several studies showed increased rates of overall and cardiovascular mortality among patients with detectable HCV RNA. ${ }^{46} \mathrm{HCV}$ infection was also an independent predictor of stroke and cerebrovascular death. ${ }^{47}$ One Asian and two Italian studies showed association with carotid atherosclerosis, suggesting that HCV infection could have a direct role in initiating the atherosclerotic plaque independent of other risk factors. ${ }^{48,49}$ This was supported by the finding that HCV induces the production of a pro-atherogenic cytokine, 
increasing the plaque instability and the risk of cardiovascular event. $^{50}$

The most common cardiovascular manifestations are acute coronary syndrome, myocarditis, and dilated or hypertrophic cardiomyopathy. Most patients, during HCV infection, develop chronic inflammation of the myocardium, dilated cardiomyopathy, necrosis and loss of myocytes. HCV infection induced proliferative stimuli, but since myocytes do not replicate, it was concluded that HCV infection promotes hypertrophy. ${ }^{51}$ Both direct viral cytotoxicity and indirect immune-mediated mechanisms may be involved in the pathogenesis of cardiovascular manifestations.

HCV stimulation of toll-like receptors, in one study, induced a CD4+ Th1 response that stimulated macrophages to produce proinflammatory cytokines, especially IL-1 and tumor necrosis factor-alpha (commonly referred to as TNF$\alpha)$. This process recruits inflammatory factors towards the myocardium and, therefore, represents a risk factor for myocarditis and cardiomyopathies. TNF- $\alpha$ caused negative inotropic effects in cardiac myocytes and stimulated the production of nitric oxide, decreasing the contractile function of the heart. Another important mechanism is gene polymorphisms in autoimmunity for human major histocompatibility complex (commonly known as MHC) class II, which may play a role in susceptibility to HCV infection. ${ }^{52}$

Recent evidence suggests that HCV infection is connected with cardiovascular abnormalities involving carotid atherosclerosis, ${ }^{45}$ although not all the findings from various studies agree. Also, SVR obtained with interferon (IFN)-based regimens was found to improve cardiovascular outcomes. ${ }^{37}$ Petta et $a l .{ }^{53}$ revealed that in HCV patients with fibrosis and compensated cirrhosis, HCV eradication by direct-acting antiviral agents (DAAs) ameliorated carotid atherosclerosis and reduced intima-media thickness, carotid thickening, and cerebrovascular and cardiovascular incidents. No changes were found in untreated patients. That study was a large prospective study on a cohort of patients with compensated HCVassociated cirrhosis who had undergone DAA-based antiviral or IFN therapies. A notable decrease in cardiovascular incidents occurred with SVR. However, this study did not distinguish between outcomes based on DAA or IFN treatment. ${ }^{54}$

Earlier retrospective analyses of a large cohort of patients in the USA demonstrated that DAA therapy decreased the frequency of cerebrovascular and cardiovascular incidents in patients with cirrhosis, in addition to decreasing the risk of cardiovascular events in patients without cirrhosis. ${ }^{55}$ Moreover, Petta et al. ${ }^{56}$ demonstrated that HCV eradication by DAA led to an increase in serum cholesterol levels, and an amelioration in blood glucose levels. This is consistent with results previously reported from cohorts of HCV patients who used DAA and IFN-based agents. Some evidence has been found linking the virus to interference with lipid metabolism and cellular glucose. ${ }^{57}$ Finally, it was demonstrated that in patients with compensated cirrhosis and fibrosis due to HCV infection, SVR by DAA ameliorated carotid atherosclerosis, which was confirmed by stratification for cardiovascular risk factors and liver disease. However, further studies are necessary to elucidate the long-term clinical implications of these results. ${ }^{58}$

\section{Neuropsychiatric disease}

Up to $50 \%$ of patients with $\mathrm{CHC}$ express neuropsychiatric manifestations, including peripheral polyneuropathy, central nervous system manifestations, and neuropsychological/psychiatric manifestations. ${ }^{41}$ Compared with the general population, HCV-infected patients have a higher prevalence of mental illness and substance abuse. ${ }^{59}$ Although this can be partly explained by the higher incidence of risk behaviors among persons with psychiatric disorders that result in HCV exposure, the recent literature suggests that the association of HCV infection with an increased prevalence of neuropsychiatric symptoms is not dependent of preexisting mental disorders or high-risk behaviors. ${ }^{60}$

Positive and negative strand HCV RNA amplification is found in brain tissue and cerebrospinal fluid, suggesting active replication. HCV has been detected in astrocytes and macrophage-microglial cells by immune-based methods, ${ }^{61}$ but the attempt to directly infect astrocytes with HCV suggested that engagement of HCV with astrocytes leads to direct neurotoxicity by strong IL-18 induction. ${ }^{62}$ Furthermore, the activation of toll-like receptors in dendritic cells caused retraction of neuronal processes mediated by extracellularsignal kinase (commonly referred to as ERK). ${ }^{63}$

Depression, chronic fatigue, and other neuropsychiatric symptoms affect the quality of life of patients with HCV infection. However, the revelation of the diagnosis itself is often accompanied by feelings of depression or anxiety. ${ }^{64}$ The treatment can further impair patient quality of life due to adverse effects, leading to poor treatment compliance which can be further compromised given the underlying mental illness. Mental health should be assessed prior to starting antiviral therapy because patients with a history of depressive disorder have a greater risk of developing depression during HCV treatment.

Patients may be treated with antidepressants or anxiolytic treatment before initiating antiviral therapy. ${ }^{65}$ Poor healthrelated quality of life (HRQoL) leads to decreased feelings of self-value and utility, depression, and consequently difficulties with interpersonal relations. The HRQoL of patients with $\mathrm{CHC}$ was found to be low compared with controls, which could not be attributed to cirrhosis because patients with cirrhosis were excluded from the study. ${ }^{66}$ In some cases, the treatment also causes symptoms that compromise HRQoL. ${ }^{67}$ On the other hand, HCV eradication improves HRQoL. ${ }^{68}$

A study on sofosbuvir (SOF) clinical trials showed that SOF and ribavirin combination was not associated with HRQOL impairment compared to placebo, and that IFN-containing regimes caused significantly more impairment in HRQOL compared to SOF. ${ }^{69}$ Overall management of $\mathrm{CHC}$ is often overlooked, and that is the reason why psychosocial assessment is important for quality of life and treatment compliance. ${ }^{70}$ Studies have shown that up to $28 \%$ of patients with $\mathrm{CHC}$ have depression. ${ }^{71}$ Although it is certainly a direct consequence of psychological burden, HCV also acts by alternating serotoninergic and dopaminergic neurotransmission. ${ }^{72}$ Depression is a consistent negative predictor of HRQoL in IFN-containing regimes, but achieving SVR has been shown to improve depression. ${ }^{73}$

Cognitive impairment is a common symptom in persons with end-stage liver disease, confirmed by the Hepatitis $C$ Antiviral Long-term Treatment against Cirrhosis (also known as HALT-C) trial, wherein $33 \%$ of patients with advanced fibrosis were found to have mild cognitive impairment. ${ }^{74}$ Forton and co-workers ${ }^{75}$ showed an association of cognitive impairment with the presence of $\mathrm{HCV}$, independent of the other neuropsychiatric symptoms, advanced fibrosis and cirrhosis, or a history of substance abuse. It is still unclear if this 
condition is a direct consequence of the infection or can be related to other comorbidities found in this population, although one pilot study suggested that HCV-infected patients who did not have other comorbidities still had higher levels of cognitive impairment than healthy controls. ${ }^{76}$ However, a prospective clinical trial has shown significant improvements in cognitive function after successful eradication of HCV infection. ${ }^{77}$

Fatigue is one of the most disabling complaints reported in more than half (prevalence: $50-67 \%$ ) of HCV-infected patients before HCV treatment, and it independently predicts poor HRQoL. ${ }^{78}$ In one prospective study, HCV was present in $53 \%$ of patients with $\mathrm{CHC}$ and associated with older age (over 50 years), female gender and the presence of cirrhosis. ${ }^{79}$ The rate of fatigue decreased significantly in patients with SVR, suggesting a direct role of the HCV infection. ${ }^{80}$

\section{Organ-specific autoimmune diseases}

\section{Thyroid disease}

Thyroid dysfunction, including chronic thyroiditis, hypothyroidism and hyperthyroidism, has been associated with HCV infection. ${ }^{81}$ An autoimmune mechanism has been proposed because of the prevalence of antithyroid autoantibodies from $4 \%$ to $15 \% .^{82}$ However, the role of $\mathrm{HCV}$ remains unclear. Patients with $\mathrm{CHC}$ are more likely to have increased levels of serum anti-thyroperoxidase and anti-thyroglobulin autoantibody than the general population, possibly due to the activation of helper T-cells. ${ }^{83}$ The development of thyroid disease was described in $11 \%$ of male HCV patients in one study, that was responsive to the treatment and reversible. ${ }^{84}$

Recently, it was confirmed that HCV could directly infect a human thyroid cell line, ML1, in vitro. On the other hand, studies have shown that dysthyroidism is mediated by immunological mechanisms rather than by direct HCV infection. The pathogenesis may involve changes in self-antigen expression and sustained stimulation of the immune system by HCV, bystander activation of autoreactive T-cells by cytokine release, infection of the lymphatic cells, chromosomal aberrations and abnormal expression of MHC class II molecules by thyrocytes, or cross-reactivity between viral antigens and thyroidal antigens. ${ }^{85}$

IFN treatment is associated with a wide range of side effects, among which thyroiditis is the most common. ${ }^{80}$ The prevalence is hard to establish due to mild symptoms and masking by other side effects or thyroid dysfunction related to the HCV infection itself. ${ }^{81}$ A classification for IFN-induced thyroiditis was proposed by Mandac et al., ${ }^{82}$ distinguishing two groups of disease: autoimmune (positive antithyroid autoantibodies in euthyroid patients, Hashimoto thyroiditis, and Graves' disease) and non-autoimmune (destructive thyroiditis and non-autoimmune hypothyroidism). The main immune effects of IFN- $\alpha$ are increased expression of MHC class I antigens on cells, immune response switching to a Th1 pattern, and enhanced activity of lymphocytes, macrophages and natural killer cells. IFN- $\alpha$ can also have a direct effect through the JAK-STAT signaling pathway, by activation of IFN-stimulated genes such as cytokine and adhesion molecule genes. Additionally, IFN- $\alpha$ can induce the necrosis of thyroid cells. ${ }^{83}$

\section{Renal disease}

Renal involvement is one of the most common severe manifestations of MC. ${ }^{86}$ Studies have shown that patients with $\mathrm{HCV}$ infection are $40 \%$ more likely to develop endstage renal disease than the general population. ${ }^{87}$ Renal manifestations of $\mathrm{CHC}$ mostly include type I membranoproliferative glomerulonephritis (MPGN) with subendothelial deposits. ${ }^{88}$ Many clinicians recommend annual screening for microalbuminuria, microscopic hematuria, and the initial stage of renal insufficiency in patients with $\mathrm{CHC}$. The Kidney Disease Improving Global Outcomes (also known as KDIGO) group recommends that all patients with kidney manifestations should be tested for HCV, and if positive treated with IFN-based antiviral treatment. ${ }^{89}$

It is important to emphasize that renal manifestations represent the main clinical feature of $M C$, reported in $14 \%$ to $63 \%$ of those patients. ${ }^{90,91}$ An acute or chronic type-I MPGN was found in $70 \%$ to $80 \%$ of cryoglobulinemic renal diseases. A typical renal presentation in MC consists of glomerular proteinuria, hematuria, and nephrotic or nephritic syndrome. Histology is typical of renal cryoglobulinemia, with glomerular endocapillary proliferation of macrophages and diffuse thickening of the glomerular basement membrane. ${ }^{86}$

Four pathogenic mechanisms of acute and chronic HCVmediated renal syndromes have been proposed: direct viral invasion of the renal parenchyma; glomerular immune complex deposition; renal complications of extrarenal manifestations; and nephrotoxicity of antiviral drugs. Perivascular inflammation and luminal occlusion by cryoglobulins and fibrin thrombi due to endothelial injury and small vessel necrosis lead to focal fibrinoid necrosis in the glomerulus. The renal tubules have ischemic and inflammatory lesions, the interstitium is edematous, and the ureteric and bladder mucosa show vasculitic purpuric lesions. The key element in the mechanism of vascular injury is $\mathrm{C} 1 \mathrm{q}$, the active complement component in the cryoglobulin complex. It causes endothelial injury by binding to endothelial complement receptors and activating the complement cascade via the classical pathway. This activation stimulates chemotactic factors C3a and C5a to recruit pro-inflammatory leukocytes, and the formation of the membrane attack complex C5-9.92 The main histological diagnostic clue is the deposition of cryoglobulins in the capillaries, caused by complement-activated glomerular endothelium and its adherence to the circulating cryoglobulins.

MPGN may occur many years after HCV infection. The mechanism is thought to be immune complex-mediated, with the formation of antigen-antibody immune complexes from chronic infection. These complexes activate the classical pathway of complements and cause deposition of immunoglobulins and complement factors in the capillary walls. Also, in patients with positive HCV RNA and MPGN, HCV-NS3 viral antigen deposits were detected in kidney tissues. ${ }^{93}$

\section{Pulmonary disease}

Idiopathic pulmonary fibrosis (IPF) is a serious condition associated with HCV infection. It is clinically characterized by dyspnea and nonproductive cough, and histologically by interstitial inflammation with dense collagen fibrosis. ${ }^{64}$ One large retrospective study in Japan compared patients with HCV infection or HBV infection with a control group. ${ }^{94}$ The incidence of IPF was significantly higher in patients with 
CHC compared to the other two groups $(0.3 \%$ at the end of the 10th year in HCV patients and none in the HBV patients), and risk factors were smoking, age, and cirrhosis.

HCV RNA was detectable in bronchoalveolar lavage fluid and lung biopsies, suggesting the direct involvement of the virus in IPF. ${ }^{95}$ However, it was concluded that immune complexes had no role in causing the IPF because immune complexes were not detected by fluorescence microscopy of the lung biopsies. A key event in the pathogenesis of IPF is virusinduced immune-mediated fibroblast activation. An increase in the levels of IL- 4 and IL-13 has been shown to result in the fibroproliferation and increased production of extracellular matrix proteins which deposit in the lungs, causing pulmonary fibrosis. ${ }^{96}$ Furthermore, HCV can exacerbate chronic obstructive pulmonary disease directly by causing chronic inflammation with increased levels of IN- 8 and TNF- $\alpha$, and indirectly by triggering T-lymphocytic response. IL-8 mediates cellular recruitment and propagates pulmonary inflammation, directly provokes bronchoconstriction and stimulates neutrophil activation. A recent study discovered a role of one HCV gene product in inducing IL-8 in lungs, suggesting that HCV can modulate the pathogenic process of obstructive pulmonary diseases. ${ }^{97}$

\section{Dermatological diseases}

HCV infection causes dermatological disorders in $17 \%$ of patients. The most common conditions are purpura and Raynaud's phenomenon. ${ }^{98}$ Palpable purpura occurs in up to $90 \%$ of cases. It is caused by extravasation of red blood cells into the dermis and appears on the skin of lower extremities. Raynaud's phenomenon is characterized by intermittent vasospasm provoked by the cold environment or emotional stress, causing cyanosis and pain of the distal digits. ${ }^{99}$ Many other skin disorders have been associated with $\mathrm{CHC}$, including porphyria cutanea tarda (PCT), lichen planus (LP), and necrolytic acral erythema.

PCT is the most common form of porphyria, caused by a deficiency of hepatic uroporphyrinogen decarboxylase and characterized by painful vesicular lesions on sun-exposed regions of the skin. ${ }^{64} \mathrm{Up}$ to $50 \%$ of PCT patients have markers of HCV infection, although a wide geographical variation in prevalence suggests the role of other genetic and environmental cofactors, such as iron overload and oxidative stress. ${ }^{100}$

The link between porphyrias, $\mathrm{CHC}$ and iron overload may lie in the increase in the rate of uroporphyrinogen oxidation to uroporphyrin. HCV increases iron stores and inhibits uroporphyrinogen decarboxylase, resulting in an accumulation of uroporphyrin and other carboxylated porphyrins in the skin, which causes the typical skin manifestations upon exposure to sunlight. Also, in the presence of uroporphyrin, photoactivation of the complement system leads to activation of mast cells and proteases, causing dermal-epidermal splitting. ${ }^{101}$ Therapy with IFN and ribavirin may exacerbate PCT manifestations, and patients may particularly benefit from IFN-free regimens.

LP is also strongly associated with $\mathrm{CHC}$. Chronic LP is considered a premalignant condition, with the potential to progress to squamous cell carcinoma, especially when involving the oral cavity. In one study, among patients with oral lichen planus (OLP), 62\% had HCV antibodies and $60 \%$ had HCV RNA. ${ }^{102}$ However, the link between HCV and LP is controversial. It is impossible to ascertain if $\mathrm{HCV}$ infection has occurred before or after skin lesions because most of the studies have been retrospective. The effect of IFN therapy has also been inconsistent, with both progression and regression reported, making it harder to elucidate the causal relationship. ${ }^{103}$

A hypothesis for the pathogenesis of LP suggests a T-cell mediated autoimmune reaction to a viral protein or a selfepitope shared by the virus. Cytotoxic CD8+ T-cells attack basal keratinocytes, which present those proteins. The subepithelial infiltration of natural killer cells, CD8+ cytotoxic Tcells, and myeloid and plasmacytoid dendritic cells releasing Th1-cytokines is the main feature of the immune dysregulation in lichenoid tissue reactions. It has been demonstrated that type-I IFNs induce the epithelial expression of myxovirus resistance protein 1 and cytotoxic T-lymphocytes' recruitment by IP-10/CXCL10-CXCR3 interaction. Proposed factors for initiation of lichenoid inflammation are viral antigens and xenobiotics presented by basal keratinocytes to immune cells. HCV may even be involved in the pathogenesis of OLP, with HCV-antigen specific CD4 and CD8 T-cells in the lesional cell-infiltrate of $\mathrm{HCV}$, resulting in the basal cell epithelial damage. ${ }^{104}$

There is a lack of information regarding the association among HCV-associated OLP and IFN-free DAA therapy. Misaka et al. ${ }^{105}$ reported a case of OLP during periodontal treatment. The patient was treated with IFN-free DAA which resulted in the amelioration of the symptoms of OLP. More investigations are necessary to evaluate the therapeutic outcomes of this therapy in these patients. The response to IFN as well as that of ledipasvir-SOF suggests that different mechanisms may be responsible for the observed effects on LP. Wiley et al. ${ }^{106}$ reported that both ledipasvir and SOF exacerbated LP, which was the first report of that kind. Moreover, upon achieving SVR with ledipasvir-SOF, their patient developed new cutaneous and genital LP. Accordingly, the authors warned of the potential of an exacerbation of LP.

Necrolytic acral erythema, characterized by painful erythematous skin lesions involving acral skin surfaces is pathognomonic for $\mathrm{CHC}{ }^{107}$ Although the etiology is not entirely clear, impairment in the regulation of zinc, which can occur in $\mathrm{CHC}$, is thought to be involved. ${ }^{108}$

\section{Ocular disease}

Several ocular manifestations have been associated with HCV. Dry eye syndrome and ischemic retinopathy are the most common. Mooren ulcer is a rare ocular complication associated with $\mathrm{CHC}$ characterized by progressive stromal ulceration, probably due to the autoimmune process against target antigens in the corneal stroma, ${ }^{109}$ which improves after IFN treatment. ${ }^{110}$

The prevalence of HCV infection in patients with primary Sjogren's syndrome (SS) was comparatively higher than in the general population, although varying geographically in different studies. Cacoub et al. ${ }^{111}$ found xerostomia and/or xeroftalmia symptoms in $10 \%$ of HCV patients. The prevalence of SS was found to be $11.9 \%$ in HCV-infected patients, whereas HCV infection was found in less than $5 \%$ of SS patients. ${ }^{112}$ The role of HCV infection in the pathogenesis of SS remains controversial because no evidence of HCV infection was found in patients with primary SS in the United States. ${ }^{113} \mathrm{HCV}$-positive SS patients suffer from vasculitis, peripheral neuropathy, and cancer more frequently than 
uninfected SS subjects, and display positivity for rheumatoid factor and serum cryoglobulinemia more frequently. ${ }^{114}$

$\mathrm{HCV}$ can infect and replicate in the salivary and lacrimal gland tissues. The virus is thought to initiate autoimmune reactions by inducing the expression of neoantigens due to molecular mimicry between viral and host antigens. This results in the production of auto-antibodies and cytotoxic Tcells directed against the host's tissues. The presence of certain periductal and perivascular infiltrates made of $B$ and $T$ CD4 lymphocytes was observed in the lachrymal gland of HCV patients. ${ }^{115}$ After the initiation of the immune response in glandular cells, there is an up-regulation of adhesion proteins and an increased production of chemokines that promote activity of antigen-presenting cells. This eventually leads to overproduction of immunoglobulins, autoantibodies and memory lymphocytes. ${ }^{116}$ The release of pro-inflammatory cytokines induces apoptosis of glandular epithelial cells, with auto-reactivation of the lymphocytes by released epitopes. This leads to destruction of the glandular parenchyma and decrease in the lachrymal secretion.

\section{Arthritis}

Arthralgia and arthritis are frequently observed EMs. Arthralgia is reported in $40-80 \%$ of HCV-infected patients, ${ }^{117}$ affecting mainly knees and hands with bilateral and symmetric pain. Rheumatoid factor activity is found in $70-80 \%$ of patients, but antibodies to cyclic citrullinated peptides are absent, which is useful in distinguishing rheumatoid arthritis (RA) from HCV arthritis. Furthermore, there are no erosive joint changes in HCV arthritis, and it often does not respond to anti-inflammatory therapy. Besides, symptoms of arthralgia and arthritis are common in adults with other forms of liver disease. According to some studies, the prevalence of these EMs was similar in patients without HCV. ${ }^{118}$ Patel et al. ${ }^{119}$ identified only $5 \% \mathrm{HCV}$ patients with RA, and they were younger, predominantly Afro-American, and smokers.

Lymphotropism of HCV plays an important role in the pathogenesis of autoimmune disorders. Chronic stimulation of the immune system by viral proteins is responsible for autoantibody production, such as of cryoglobulins and rheumatoid factor. Furthermore, increased IL-6 levels play a role in RA and HCV-related arthritis but this is not related to HCV viremia. Although still not elucidated, possible mechanisms in which HCV triggers arthritis include direct invasion of the synovial tissue, autoimmune response to the virus, and immune complex or cryoglobulin deposition which may trigger local inflammation in the synovium. However, antiCCP antibodies, found in $60-75 \%$ of patients, are specific for RA $(96-98 \%)$ and more predictive of more aggressive and erosive RA. ${ }^{120}$

\section{Therapeutic implications}

International recommendations on the treatment of $\mathrm{HCV}$ patients with EMs are still not developed. DAAs are a new medication with short duration of treatment, minimum adverse effects, and almost $100 \%$ efficacy. ${ }^{121}$ Effective antiviral treatment significantly improved the symptoms of EMs and reduced the risk of complications, so it should be given to all HCV patients with EMs, even if the liver disease is not serious and there is no hepatic fibrosis.

Regimens based on DAAs should be considered the standard approach for patients with EMs, who should be treated according to the DAA international recommendations for monoinfected patients. Patients with a more severe condition should be treated first, in case of limited resources. Although elimination of the HCV relieves EMs, the selection of antiviral drugs should be made with caution to avoid worsening EMs or cause adverse reactions. Therefore, in order to choose appropriate antiviral treatment, along with the stage of liver disease, the characteristics and severity of extrahepatic diseases should be evaluated. ${ }^{122}$

Many studies have shown marked improvement of EMs upon eradication of HCV with peg-IFN and ribavirin. Evidence has included clearance of cryoglobulins, reduced IR, reduced stroke risk, resolution of dermatological EMs, improved HRQoL with improved work productivity, and reduced depression. ${ }^{123,124}$ In one Italian study on 44 patients, SOF was associated with regression of all vasculitis symptoms in $36 \%$, and improvement of MC symptoms in $41 \%$ of patients. However, there was variation in the rates of improvement of various features of MC vasculitis. For example, purpura and kidney disease improved faster than fatigue and neuropathy. ${ }^{125}$ More studies are needed to evaluate MC outcomes in patients who achieve SVR.

For lymphoproliferative disorders, antiviral treatment results in a hematologic response in up to $70 \%$ of patients in different studies. ${ }^{126}$ Considering HCV-related renal disease, IFN-based treatment resulted in renal disease improvement but caused anemia. On the other hand, IFNfree regimes showed a serologic response with proteinuria decrease in more than $80 \%$ of patients, and with no need for erythropoietin. ${ }^{127}$ A large cohort study including 2842 patients from Japan indicated that achievement of SVR was independently associated with a reduced risk for occurrence of T2DM, with $11 \%$ of SVR patients in comparison to $24 \%$ of non-SVR patients having developed glucose abnormalities in a 27-month follow-up. ${ }^{128}$

$\mathrm{HCV}$ eradication also positively modified cardiovascular outcomes in HCV patients. One study from Taiwan found that treatment was associated with a $47 \%$ risk reduction for ischemic stroke and $36 \%$ for acute coronary syndrome in IFN-treated patients compared to untreated controls. ${ }^{128}$ These results pointed out the fact that the stage of liver disease should not be the only parameter used to decide on antiviral therapy in patients with chronic HCV infection. Antiviral treatment was shown to improve HRQoL in patients achieving viral eradication with an improved neurocognitive function, such as attention and vigilance. ${ }^{129}$ Furthermore, IFN-free treatment improved cutaneous manifestation with complete disappearance of LP in three out of seven patients after antiviral therapy. ${ }^{130}$

\section{Conclusions}

Chronic HCV infection can cause significant EMs and should be considered as a systemic disease rather than a single (liver) disease. It is important to emphasize that the severity of these disorders does not necessarily correlate with the severity of hepatic disease because even in cases of quietly active chronic hepatitis, a substantial interruption of health and quality of life can occur. Some investigations have shown that therapy of chronic HCV infection can result in resolution of extrahepatic disease or improvement in the function of affected organs, decreasing morbidity and mortality risks. Patients with systemic manifestations of HCV infection should have priority for IFN-free therapies. Therapeutic advances in 
the treatment of $\mathrm{HCV}$ have the potential to eliminate or improve HCV extrahepatic manifestations.

\section{Conflict of interest}

The authors have no conflict of interests related to this publication.

\section{Author contributions}

Conceived of and designed the article, and critically revised the manuscript (GYW), performed critical revision of the manuscript for important intellectual content, obtained funding, and provided administrative, technical and material support (MS), performed literature searches and critical revision of the manuscript for important intellectual content (RS), performed literature searches, wrote the manuscript, and updated the text of the paper (LK), performed literature searches and wrote the manuscript (JJ).

\section{References}

[1] Rosenthal E, Cacoub P. Extrahepatic manifestations in chronic hepatitis C virus carriers. Lupus 2015;24:469-482. doi: 10.1177/096120331455 6140.

[2] Austria AM, Ninčević V, Wu GY. A brief update on the treatment of hepatitis C. In: Smolic M, Vcev A, Wu GY, ed. Update on hepatitis C. IntechOpen, 2017:3-16. doi: 10.5772/intechopen.70685.

[3] Virovic Jukic L, Kralj D. Extrahepatic Manifestations of Hepatitis C Virus Infection. In: Smolic M, Vcev A, Wu GY, ed. Update on hepatitis C. IntechOpen, 2017:111-124. doi: 10.5772/intechopen.70728.

[4] Flores-Chávez A, Carrion JA, Forns X, Ramos-Casals M. Extrahepatic manifestations associated with Chronic Hepatitis C Virus Infection. Rev Esp Sanid Penit 2017;19:87-97. doi: 10.4321/S1575-06202017000300004.

[5] Ramos-Casals M, Stone JH, Cid MC, Bosch X. The cryoglobulinaemias. Lancet 2012;379:348-360. doi: 10.1016/S0140-6736(11)60242-0.

[6] Lunel F, Musset L. Hepatitis C virus infection and cryoglobulinemia. J Hepatol 1998;29:848-855. doi: 10.1016/S0168-8278(98)80270-5.

[7] Pawlotsky JM, Ben Yahia M, Andre C, Voisin MC, Intrator L, Roudot-Thoraval $\mathrm{F}$, et al. Immunological disorders in $\mathrm{C}$ virus chronic active hepatitis: a prospective case-control study. Hepatology 1994;19:841-848. doi: 10. 1002/hep.1840190407.

[8] Sene D, Ghillani-Dalbin P, Thibault V, Guis L, Musset L, Duhaut P, et al. Longterm course of mixed cryoglobulinemia in patients infected with hepatitis $C$ virus. J Rheumatol 2004;31:2199-2206. doi: 10.1016/s0168-8278(04) 90468-0.

[9] Jacobson IM, Cacoub P, Dal Maso L, Harrison SA, Younossi ZM. Manifestations of chronic hepatitis $C$ virus infection beyond the liver. Clin Gastroenterol Hepatol 2010;8:1017-1029. doi: 10.1016/j.cgh.2010.08.026.

[10] Stefanova-Petrova DV, Tzvetanska AH, Naumova EJ, Mihailova AP, Hadjiev EA, Dikova RP, et al. Chronic hepatitis C virus infection: prevalence of extrahepatic manifestations and association with cryoglobulinemia in Bulgarian patients. World J Gastroenterol 2007;13:6518-6528. doi: 10.3748/wjg. v13.i48.6518.

[11] Alpers CE, Smith KD. Cryoglobulinemia and renal disease. Curr Opin Nephrol Hypertens 2008;17:243-249. doi: 10.1097/MNH.0b013e3282 f8afe2.

[12] Ferri C, Sebastiani M, Giuggioli D, Cazzato M, Longombardo G, Antonelli A, et al. Mixed cryoglobulinemia: demographic, clinical, and serologic features and survival in 231 patients. Semin Arthritis Rheum 2004;33:355-374. doi: 10.1016/j.semarthrit.2003.10.001.

[13] Terrier B, Semoun O, Saadoun D, Sène D, Resche-Rigon M, Cacoub P. Prognostic factors in patients with hepatitis $C$ virus infection and systemic vasculitis. Arthritis Rheum 2011;63:1748-1757. doi: 10.1002/art.30319.

[14] Jabłońska J, Zạbek J, Pawełczyk A, Kubisa N, Fic M, Laskus T, et al. Hepatitis $C$ virus (HCV) infection of peripheral blood mononuclear cells in patients with type II cryoglobulinemia. Hum Immunol 2013;74:1559-1562. doi: 10.1016/j.humimm.2013.08.273.

[15] Dai B, Chen AY, Corkum CP, Peroutka RJ, Landon A, Houng S, et al. Hepatitis $C$ virus upregulates $B$-cell receptor signaling: a novel mechanism for HCV-associated B-cell lymphoproliferative disorders. Oncogene 2016;35: 2979-2990. doi: 10.1038/onc.2015.364.
[16] Chen $\mathrm{CL}$, Huang JY, Wang $\mathrm{CH}$, Tahara SM, Zhou L, Kondo $\mathrm{Y}$, et al. Hepatitis C virus has a genetically determined lymphotropism through co-receptor B7. 2. Nat Commun 2017;8:13882. doi: 10.1038/ncomms13882.

[17] Couronné L, Bachy E, Roulland S, Nadel B, Davi F, Armand M, et al. From hepatitis $C$ virus infection to B-cell lymphoma. Ann Oncol 2018;29:92-100. doi: 10.1093/annonc/mdx635.

[18] Monti G, Pioltelli P, Saccardo F, Campanini M, Candela M, Cavallero G, et al. Incidence and characteristics of non-Hodgkin lymphomas in a multicenter case file of patients with hepatitis $C$ virus-related symptomatic mixed cryoglobulinemias. Arch Intern Med 2005;165:101-105. doi: 10.1001/ archinte.165.1.101.

[19] Charles ED, Green RM, Marukian S, Talal AH, Lake-Bakaar GV, Jacobson IM, et al. Clonal expansion of immunoglobulin $\mathrm{M}+\mathrm{CD} 27+\mathrm{B}$ cells in HCVassociated mixed cryoglobulinemia. Blood 2008;111:1344-1356. doi: 10. 1182/blood-2007-07-101717.

[20] Zignego AL, Macchia D, Monti M, Thiers V, Mazzetti M, Foschi M, et al. Infection of peripheral mononuclear blood cells by hepatitis $C$ virus. J Hepatol 1992;15:382-386. doi: 10.1016/0168-8278(92)90073-X.

[21] Zignego AL, Giannini C, Gragnani L. HCV and lymphoproliferation. Clin Dev Immunol 2012;2012:980942. doi: 10.1155/2012/980942.

[22] Gisbert JP, García-Buey L, Pajares JM, Moreno-Otero R. Prevalence of hepatitis C virus infection in B-cell non-Hodgkin's lymphoma: systematic review and meta-analysis. Gastroenterology 2003;125:1723-1732. doi: 10.1053/j.gastro.2003.09.025.

[23] Machida K, Cheng KT, Sung VM, Shimodaira S, Lindsay KL, Levine AM, et al. Hepatitis $C$ virus induces a mutator phenotype: enhanced mutations of immunoglobulin and protooncogenes. Proc Natl Acad Sci U S A 2004;101: 4262-4267. doi: 10.1073/pnas.0303971101.

[24] Suarez F, Lortholary O, Hermine O, Lecuit M. Infection-associated lymphomas derived from marginal zone $B$ cells: a model of antigen-driven lymphoproliferation. Blood 2006;107:3034-3044. doi: 10.1182/blood-2005-093679.

[25] Peveling-Oberhag J, Arcaini L, Hansmann ML, Zeuzem S. Hepatitis C-associated B-cell non-Hodgkin lymphomas. Epidemiology, molecular signature and clinical management. J Hepatol 2013;59:169-177. doi: 10. 1016/j.jhep.2013.03.018.

[26] Ng PP, Kuo CC, Wang S, Einav S, Arcaini L, Paulli M, et al. B-cell receptors expressed by lymphomas of hepatitis $C$ virus (HCV)-infected patients rarely react with the viral proteins. Blood 2014;123:1512-1515. doi: 10 . 1182/blood-2013-10-532895.

[27] Vannata B, Zucca E. Hepatitis C virus-associated B-cell non-Hodgkin lymphomas. Hematology Am Soc Hematol Educ Program 2014;2014: 590-598. doi: 10.1182/asheducation-2014.1.590.

[28] Wang CS, Wang ST, Yao WJ, Chang TT, Chou P. Hepatitis C virus infection and the development of type 2 diabetes in a community-based longitudinal study. Am J Epidemiol 2007;166:196-203. doi: 10.1093/aje/kwm061.

[29] Zein CO, Levy C, Basu A, Zein NN. Chronic hepatitis C and type II diabetes mellitus: a prospective cross-sectional study. Am J Gastroenterol 2005; 100:48-55. doi: 10.1111/j.1572-0241.2005.40429.x.

[30] Lecube A, Hernández C, Genescà J, Simó R. Glucose abnormalities in patients with hepatitis $C$ virus infection: Epidemiology and pathogenesis. Diabetes Care 2006;29:1140-1149. doi: 10.2337/diacare.2951140.

[31] Antonelli A, Ferri C, Fallahi P, Sebastiani M, Nesti C, Barani L, et al. Type 2 diabetes in hepatitis C-related mixed cryoglobulinaemia patients. Rheumatology (Oxford) 2004;43:238-240. doi: 10.1093/rheumatology/keh011.

[32] White DL, Ratziu V, El-Serag HB. Hepatitis C infection and risk of diabetes: a systematic review and meta-analysis. J Hepatol 2008;49:831-844. doi: 10. 1016/j.jhep.2008.08.006.

[33] Stepanova M, Lam B, Younossi Y, Srishord MK, Younossi ZM. Association of hepatitis $C$ with insulin resistance and type 2 diabetes in US general population: the impact of the epidemic of obesity. J Viral Hepat 2012;19: 341-345. doi: 10.1111/j.1365-2893.2011.01554.x.

[34] Mangia A, Ripoli $M$. Insulin resistance, steatosis and hepatitis $C$ virus. Hepatol Int 2013;7 Suppl 2:782-789. doi: 10.1007/s12072-013-9460-1.

[35] Moucari R, Asselah T, Cazals-Hatem D, Voitot H, Boyer N, Ripault MP, et al. Insulin resistance in chronic hepatitis $\mathrm{C}$ : association with genotypes 1 and 4, serum HCV RNA level, and liver fibrosis. Gastroenterology 2008;134: 416-423. doi: 10.1053/j.gastro.2007.11.010.

[36] Shaheen M, Echeverry D, Oblad MG, Montoya MI, Teklehaimanot S, Akhtar AJ. Hepatitis C, metabolic syndrome, and inflammatory markers: results from the Third National Health and Nutrition Examination Survey [NHANES III]. Diabetes Res Clin Pract 2007;75:320-326. doi: 10.1016/j. diabres.2006.07.008.

[37] Hsu YC, Lin JT, Ho HJ, Kao YH, Huang YT, Hsiao NW, et al. Antiviral treatment for hepatitis $\mathrm{C}$ virus infection is associated with improved renal and cardiovascular outcomes in diabetic patients. Hepatology 2014;59:1293-1302. doi: 10.1002/hep.26892. 
[38] Wang $Q$, Chen J, Wang $Y$, Han $X$, Chen $X$. Hepatitis $C$ virus induced a novel apoptosis-like death of pancreatic beta cells through a caspase 3-dependent pathway. PLoS One 2012;7:e38522. doi: 10.1371/journal. pone.0038522.

[39] Prentki M, Joly E, El-Assaad W, Roduit R. Malonyl-CoA signaling, lipid partitioning, and glucolipotoxicity: role in beta-cell adaptation and failure in the etiology of diabetes. Diabetes 2002;51:S405-S413. doi: 10 . 2337/diabetes.51.2007.S405.

[40] Leahy JL. Pathogenesis of type 2 diabetes mellitus. Arch Med Res 2005;36: 197-209. doi: 10.1016/j.arcmed.2005.01.003.

[41] Ferri C, Ramos-Casals M, Zignego AL, Arcaini L, Roccatello D, Antonelli $A$, et al. International diagnostic guidelines for patients with HCV-related extrahepatic manifestations. A multidisciplinary expert statement. Autoimmun Rev 2016;15:1145-1160. doi: 10.1016/j.autrev.2016.09.006.

[42] Dai CY, Chuang WL, Ho CK, Hsieh MY, Huang JF, Lee LP, et al. Associations between hepatitis $\mathrm{C}$ viremia and low serum triglyceride and cholestero levels: a community-based study. J Hepatol 2008;49:9-16. doi: 10 . 1016/j.jhep.2008.03.016.

[43] Roed T, Lebech AM, Kjaer A, Weis N. Hepatitis C virus infection and risk of coronary artery disease: a systematic review of the literature. Clin Physio Funct Imaging 2012;32:421-430. doi: 10.1111/j.1475-097X.2012. 01152.x.

[44] Hsu YH, Muo CH, Liu CY, Tsai WC, Hsu CC, Sung FC, et al. Hepatitis C virus infection increases the risk of developing peripheral arterial disease: 9-year population-based cohort study. J Hepatol 2015;62:519-525. doi: 10.1016/j.jhep.2014.09.022.

[45] Adinolfi LE, Restivo L, Zampino R, Guerrera B, Lonardo A, Ruggiero L, et al. Chronic HCV infection is a risk of atherosclerosis. Role of HCV and HCV-related steatosis. Atherosclerosis 2012;221:496-502. doi: 10 . 1016/j.atherosclerosis.2012.01.051

[46] Lee $\mathrm{MH}$, Yang HI, Lu SN, Jen CL, You SL, Wang LY, et al. Chronic hepatitis $\mathrm{C}$ virus infection increases mortality from hepatic and extrahepatic diseases: a community-based long-term prospective study. J Infect Dis 2012;206: 469-477. doi: 10.1093/infdis/jis385.

[47] Liao CC, Su TC, Sung FC, Chou WH, Chen TL. Does hepatitis C virus infection increase risk for stroke? A population-based cohort study. PLoS One 2012; 7:e31527. doi: 10.1371/journal.pone.0031527.

[48] Fukui M, Kitagawa $Y$, Nakamura N, Yoshikawa T. Hepatitis $C$ virus and atherosclerosis in patients with type 2 diabetes. JAMA 2003;289:1245-1246. doi: 10.1001/jama.289.10.1245-a.

[49] Palm F, Urbanek C, Grau A. Infection, its treatment and the risk for stroke. Curr Vasc Pharmacol 2009;7:146-152. doi: 10.2174/157016109787455 707.

[50] Libby P, Aikawa M. Stabilization of atherosclerotic plaques: new mechanisms and clinical targets. Nat Med 2002;8:1257-1262. doi: 10. 1038/nm1102-1257.

[51] Ilyas SZ, Tabassum R, Hamed H, Rehman SU, Qadri I. Hepatitis C virusassociated extrahepatic manifestations in lung and heart and antivira therapy-related cardiopulmonary toxicity. Viral Immunol 2017;30:633641. doi: 10.1089/vim.2017.0009.

[52] Sanchez MJ, Bergasa NV. Hepatitis C associated cardiomyopathy: potential pathogenic mechanisms and clinical implications. Med Sci Monit 2008;14: RA55-RA63.

[53] Chambless LE, Heiss G, Folsom AR, Rosamond W, Szklo M, Sharrett AR, et al. Association of coronary heart disease incidence with carotid arteria wall thickness and major risk factors: the Atherosclerosis Risk in Communities (ARIC) Study, 1987-1993. Am J Epidemiol 1997;146:483-494. doi: 10.1093/oxfordjournals.aje.a009302

[54] Cacoub P, Nahon P, Layese R, Bourcier V, Cagnot C, Marcellin P, et al. HCV eradication reduces the occurrence of major adverse cardiovascular events in hepatitis C cirrhotic patients: data from the prospective ANRS CO12 CirVir cohort. J Hepatol 2017;66:S20-S21. doi: 10.1016/S0168-8278 (17)30303-3

[55] Singer AW, Osinusi A, Brainard DM, Chokkalingam AP. Risk of cardiovascular and cerebrovascular events in hepatitis $C$ patients following completion of direct-acting antiviral therapy: a retrospective cohort study. J Hepato 2017;66:S282-S283. doi: 10.1016/S0168-8278(17)30882-6.

[56] Afdhal N, Zeuzem S, Kwo P, Chojkier M, Gitlin N, Puoti M, et al. Ledipasvir and sofosbuvir for untreated HCV genotype 1 infection. N Engl J Med 2014 370:1889-1898. doi: 10.1056/NEJMoa1402454.

[57] Bugianesi E, Salamone F, Negro F. The interaction of metabolic factors with HCV infection: does it matter? J Hepatol 2012;56:S56-S65. doi: 10 1016/S0168-8278(12)60007-5.

[58] Petta S, Adinolfi LE, Fracanzani AL, Rini F, Caldarella R, Calvaruso V, et al. Hepatitis $C$ virus eradication by direct-acting antiviral agents improves carotid atherosclerosis in patients with severe liver fibrosis. J Hepatol 2018;69:18-24. doi: 10.1016/j.jhep.2018.02.015.
[59] Butt AA, Khan UA, McGinnis KA, Skanderson M, Kent Kwoh C. Co-morbid medical and psychiatric illness and substance abuse in HCV-infected and uninfected veterans. J Viral Hepat 2007;14:890-896. doi: 10.1111/j. 1365-2893.2007.00885.x.

[60] Negro F, Forton D, Craxì A, Sulkowski MS, Feld J], Manns MP. Extrahepatic morbidity and mortality of chronic hepatitis C. Gastroenterology $2015 ; 149$ 1345-1360. doi: 10.1053/j.gastro.2015.08.035.

[61] Letendre S, Paulino AD, Rockenstein E, Adame A, Crews L, Cherner M, et al. Pathogenesis of hepatitis $C$ virus coinfection in the brains of patients infected with HIV. J Infect Dis 2007;196:361-370. doi: 10.1086/519285.

[62] Liu Z, Zhao $F$, He J]. Hepatitis C virus (HCV) interaction with astrocytes: nonproductive infection and induction of IL-18. J Neurovirol 2014;20: 278-293. doi: 10.1007/s13365-014-0245-7.

[63] Paulino AD, Ubhi K, Rockenstein E, Adame A, Crews L, Letendre S, et al. Neurotoxic effects of the HCV core protein are mediated by sustained activation of ERK via TLR2 signaling. J Neurovirol 2011;17:327-340. doi: 10 . 1007/s13365-011-0039-0.

[64] Gill K, Ghazinian H, Manch R, Gish R. Hepatitis C virus as a systemic disease: reaching beyond the liver. Hepatol Int 2016;10:415-423. doi: 10.1007/s12072-015-9684-3.

[65] Raison CL, Borisov AS, Broadwell SD, Capuron L, Woolwine BJ, Jacobson IM, et al. Depression during pegylated interferon-alpha plus ribavirin therapy: prevalence and prediction. J Clin Psychiatry 2005;66:41-48. doi: 10 . 4088/jcp.v66n0106.

[66] Bonkovsky HL, Snow KK, Malet PF, Back-Madruga C, Fontana RJ, Sterling RK, et al. Health-related quality of life in patients with chronic hepatitis C and advanced fibrosis. J Hepatol 2007;46:420-431. doi: 10.1016/j.jhep. 2006.10.009.

[67] Marcellin P, Chousterman M, Fontanges T, Ouzan D, Rotily M, Varastet M, et al. Adherence to treatment and quality of life during hepatitis $C$ therapy: prospective, real-life, observational study. Liver Int 2011;31:516-524. doi: 10.1111/j.1478-3231.2011.02461.x

[68] Cacoub $\mathrm{P}$, Lidove O, Maisonobe T, Duhaut $\mathrm{P}$, Thibault V, Ghillani $\mathrm{P}$, et al. Interferon-alpha and ribavirin treatment in patients with hepatitis $C$ virusrelated systemic vasculitis. Arthritis Rheum 2002;46:3317-3326. doi: 10. 1002/art.10699.

[69] Younossi ZM, Stepanova M, Mishra A, Venkatesan C, Henry L, Hunt S. The impact of chronic hepatitis $C$ on resource utilisation and in-patient mortality for Medicare beneficiaries between 2005 and 2010. Aliment Pharmacol Ther 2013;38:1065-1075. doi: 10.1111/apt.12485.

[70] Modabbernia A, Poustchi H, Malekzadeh R. Neuropsychiatric and psychosocial issues of patients with hepatitis $C$ infection: a selective literature review. Hepat Mon 2013;13:e8340. doi: 10.5812/hepatmon.8340.

[71] Golden J, O'Dwyer AM, Conroy RM. Depression and anxiety in patients with hepatitis C: prevalence, detection rates and risk factors. Gen Hosp Psychiatry 2005;27:431-438. doi: 10.1016/j.genhosppsych.2005.06.006.

[72] Forton DM. Altered monoaminergic transporter binding in hepatitis $C$ related cerebral dysfunction: a neuroimmunologial condition? Gut 2006;55:15351537. doi: $10.1136 /$ gut.2006.100081.

[73] Boscarino JA, Lu M, Moorman AC, Gordon SC, Rupp LB, Spradling PR, et al. Predictors of poor mental and physical health status among patients with chronic hepatitis $\mathrm{C}$ infection: the Chronic Hepatitis Cohort Study (CHeCS). Hepatology 2015;61:802-811. doi: 10.1002/hep.27422.

[74] Fontana RJ, Bieliauskas LA, Back-Madruga C, Lindsay KL, Kronfol Z, Lok AS et $a$ l. Cognitive function in hepatitis $C$ patients with advanced fibrosis enrolled in the HALT-C trial. J Hepatol 2005;43:614-622. doi: $10.1016 / \mathrm{j}$. jhep.2005.04.006

[75] Forton DM, Thomas HC, Murphy CA, Allsop JM, Foster GR, Main J, et al. Hepatitis $C$ and cognitive impairment in a cohort of patients with mild liver disease. Hepatology 2002;35:433-439. doi: 10.1053/jhep.2002. 30688.

[76] Lowry D, Coughlan B, McCarthy O, Crowe J. Investigating health-related quality of life, mood and neuropsychological test performance in a homogeneous cohort of Irish female hepatitis C patients. J Viral Hepat 2010;17: 352-359. doi: 10.1111/j.1365-2893.2009.01188.x.

[77] Thein $\mathrm{HH}$, Maruff $\mathrm{P}$, Krahn MD, Kaldor JM, Koorey DJ, Brew BJ, et al. Improved cognitive function as a consequence of hepatitis $C$ virus treatment. HIV Med 2007;8:520-528. doi: 10.1111/j.1468-1293.2007. 00505.x.

[78] Kallman J, O’Neil MM, Larive B, Boparai N, Calabrese L, Younossi ZM. Fatigue and health-related quality of life (HRQL) in chronic hepatitis C virus infection. Dig Dis Sci 2007;52:2531-2539. doi: 10.1007/s10620006-9708-x.

[79] Poynard T, Cacoub P, Ratziu V, Myers RP, Dezailles MH, Mercadier A, et al. Fatigue in patients with chronic hepatitis C. J Viral Hepat 2002;9:295-303. doi: $10.1046 / j .1365-2893.2002 .00364 . x$

[80] Cacoub P, Ratziu V, Myers RP, Ghillani P, Piette JC, Moussalli J, et al. Impact of treatment on extra hepatic manifestations in patients with chronic 
hepatitis C. J Hepatol 2002;36:812-818. doi: 10.1016/S0168-8278(02) 00067-3.

[81] Mao XR, Zhang LT, Chen H, Xiao P, Zhang YC. Possible factors affecting thyroid dysfunction in hepatitis $C$ virus-infected untreated patients. Exp Ther Med 2014;8:133-140. doi: 10.3892/etm.2014.1709.

[82] Broussolle C, Steineur MP, Bailly F, Zoulim F, Trépo C. Hepatitis C virus infection and thyroid diseases. Rev Med Interne 1999;20:766-773. doi: 10.1016/S0248-8663(00)88683-X.

[83] Fallahi P, Ferrari SM, Giuggioli D, Manfredi A, Mancusi C, Fabiani S, et al. Thyroid involvement in hepatitis C - associated mixed cryoglobulinemia. Hormones (Athens) 2014;13:16-23. doi: 10.1007/bf03401317.

[84] Bini EJ, Mehandru S. Incidence of thyroid dysfunction during interferon alfa$2 \mathrm{~b}$ and ribavirin therapy in men with chronic hepatitis C: a prospective cohort study. Arch Intern Med 2004;164:2371-2376. doi: 10.1001/ archinte.164.21.2371.

[85] Shen Y, Wang XL, Xie JP, Shao JG, Lu YH, Zhang S, et al. Thyroid disturbance in patients with chronic hepatitis $\mathrm{C}$ infection: A systematic review and metaanalysis. J Gastrointestin Liver Dis 2016;25:227-234. doi: 10.15403/jgld. 2014.1121.252.chc.

[86] Zaidan M, Mariotte E, Galicier L, Arnulf B, Meignin V, Vérine J, et al. Vasculitic emergencies in the intensive care unit: a special focus on cryoglobulinemic vasculitis. Ann Intensive Care 2012;2:31. doi: 10.1186/2110-5820-2-31.

[87] Tsui JI, Vittinghoff E, Shlipak MG, Bertenthal D, Inadomi J, Rodriguez RA, et al. Association of hepatitis $C$ seropositivity with increased risk for developing end-stage renal disease. Arch Intern Med 2007;167:1271-1276. doi: 10.1001/archinte.167.12.1271.

[88] Dalrymple LS, Koepsell T, Sampson J, Louie T, Dominitz JA, Young B, et al. Hepatitis $C$ virus infection and the prevalence of renal insufficiency. Clin J Am Soc Nephrol 2007;2:715-721. doi: 10.2215/CJN.00470107.

[89] Matuszkiewicz-Rowińska J. KDIGO clinical practice guidelines for the diagnosis, evaluation, prevention, and treatment of mineral and bone disorders in chronic kidney disease. Pol Arch Med Wewn 2010;120:300-306.

[90] Mandac JC, Chaudhry S, Sherman KE, Tomer Y. The clinical and physiological spectrum of interferon-alpha induced thyroiditis: toward a new classification. Hepatology 2006;43:661-672. doi: 10.1002/hep.21146.

[91] Tomer Y. Hepatitis C and interferon induced thyroiditis. ] Autoimmun 2010; 34:J322-J326. doi: 10.1016/j.jaut.2009.11.008

[92] Azmi AN, Tan SS, Mohamed R. Hepatitis C and kidney disease: An overview and approach to management. World J Hepatol 2015;7:78-92. doi: 10. 4254/wjh.v7.i1.78.

[93] Bataille S, Kaplanski G, Boucraut J, Halfon P, Camus C, Daniel L, et al. Membranoproliferative glomerulonephritis and mixed cryoglobulinemia after hepatitis $C$ virus infection secondary to glomerular NS3 viral antigen deposits. Am J Nephrol 2012;35:134-140. doi: 10.1159/000335375.

[94] Arase Y, Suzuki F, Suzuki Y, Akuta N, Kobayashi M, Kawamura Y, et al. Hepatitis $C$ virus enhances incidence of idiopathic pulmonary fibrosis. World J Gastroenterol 2008;14:5880-5886. doi: $10.3748 /$ wjg.14.5880.

[95] Brunetti G, Delmastro M, Nava S, Pignatti P, Bossi A, Gatti M, et al. Detection of HCV-RNA in bronchoalveolar lavage from a woman with pulmonary fibrosis. Respir Med 2003;97:736-738. doi: 10.1053/rmed.2003.1489.

[96] Wynn TA. Integrating mechanisms of pulmonary fibrosis. J Exp Med 2011; 208:1339-1350. doi: 10.1084/jem.20110551.

[97] Kanazawa H. Relationship between hepatitis $\mathrm{C}$ virus infection and pulmonary disorders: potential mechanisms of interaction. Expert Rev Clin Immunol 2006;2:801-810. doi: 10.1586/1744666X.2.5.801.

[98] Cacoub P, Poynard T, Ghillani P, Charlotte F, Olivi M, Piette JC, et al. Extrahepatic manifestations of chronic hepatitis C. MULTIVIRC Group. Multidepartment Virus C. Arthritis Rheum 1999;42:2204-2212. doi: 10 1002/1529-0131(199910)42:10<2204::AID-ANR24>3.0.CO;2-D.

[99] Schamberg NJ, Lake-Bakaar GV. Hepatitis C virus-related mixed cryoglobulinemia: pathogenesis, clinica manifestations, and new therapies. Gastroenterol Hepatol (N Y) 2007;3:695-703.

[100] Gisbert JP, García-Buey L, Pajares JM, Moreno-Otero R. Prevalence of hepatitis $C$ virus infection in porphyria cutanea tarda: systematic review and meta-analysis. J Hepatol 2003;39:620-627. doi: 10.1016/S0168-8278 (03)00346-5.

[101] Dedania B, Wu GY. Dermatologic extrahepatic manifestations of hepatitis C. J Clin Transl Hepatol 2015;3:127-133. doi: 10.14218/JCTH.2015.00010.

[102] Gandolfo S, Carrozzo M. Lichen planus and hepatitis $C$ virus infection. Minerva Gastroenterol Dietol 2002;48:89.

[103] Carrozzo M, Scally K. Oral manifestations of hepatitis $C$ virus infection. World J Gastroenterol 2014;20:7534-7543. doi: 10.3748/wjg.v20.i24. 7534.

[104] Garcovich S, Garcovich M, Capizzi R, Gasbarrini A, Zocco MA. Cutaneous manifestations of hepatitis $C$ in the era of new antiviral agents. World J Hepatol 2015;7:2740-2748. doi: 10.4254/wjh.v7.i27.2740.

[105] Misaka K, Kishimoto T, Kawahigashi Y, Sata M, Nagao Y. Use of direct-acting antivirals for the treatment of hepatitis $C$ virus-associated oral lichen planus: A case report. Case Rep Gastroenterol 2016;10:617-622. doi: 10.1159/000450679.
[106] Lawitz E, Matusow G, DeJesus E, Yoshida EM, Felizarta F, Ghalib R, et al. Simeprevir plus sofosbuvir in patients with chronic hepatitis $C$ virus genotype 1 infection and cirrhosis: A phase 3 study (OPTIMIST-2). Hepatology 2016;64:360-369. doi: 10.1002/hep.28422.

[107] Kapoor R, Johnson RA. Necrolytic acral erythema. N Engl J Med 2011;364: 1479-1480. doi: 10.1056/NEJMc1101858.

[108] Ko HM, Hernandez-Prera JC, Zhu H, Dikman SH, Sidhu HK, Ward SC, et al. Morphologic features of extrahepatic manifestations of hepatitis $\mathrm{C}$ virus infection. Clin Dev Immunol 2012;2012:740138. doi: 10.1155/2012/ 740138.

[109] Tsoumani A, Theopistos V, Katsanos K, Asproudis I, Tsianos EV. Treatment and non-treatment related ocular manifestations in patients with chronic hepatitis B or C. Eur Rev Med Pharmacol Sci 2013;17:1123-1131.

[110] Wilson SE, Lee WM, Murakami C, Weng J, Moninger GA. Mooren-type hepatitis C virus-associated corneal ulceration. Ophthalmology 1994;101: 736-745. doi: 10.1016/S0161-6420(94)31291-7.

[111] Cacoub P, Renou C, Rosenthal E, Cohen P, Loury I, Loustaud-Ratti V, et al. Extrahepatic manifestations associated with hepatitis $C$ virus infection. A prospective multicenter study of 321 patients. The GERMIVIC. Groupe d'Etude et de Recherche en Medecine Interne et Maladies Infectieuses sur le Virus de I'Hepatite C. Medicine (Baltimore) 2000;79:47-56. doi: 10. 1097/00005792-200001000-00005.

[112] Romano C, Cuomo G, Ferrara R, Del Mastro A, Esposito S, Sellitto A, et al. Uncommon immune-mediated extrahepatic manifestations of HCV infection. Expert Rev Clin Immunol 2018;14:1089-1099. doi: 10. 1080/1744666X.2018.1538790.

[113] Marrone A, Di Bisceglie AM, Fox P. Absence of hepatitis C viral infection among patients with primary Sjögren's syndrome. J Hepatol 1995;22: 599. doi: 10.1016/0168-8278(95)80461-7

[114] Brito-Zerón P, Gheitasi H, Retamozo S, Bové A, Londoño M, Sánchez-Tapias $\mathrm{JM}$, et al. How hepatitis $C$ virus modifies the immunological profile of Sjögren syndrome: analysis of 783 patients. Arthritis Res Ther 2015;17: 250. doi: 10.1186/s13075-015-0766-3.

[115] Alves M, Angerami RN, Rocha EM. Dry eye disease caused by viral infection: review. Arq Bras Oftalmol 2013;76:129-132. doi: 10.1590/S000427492013000200016

[116] Anisia-Iuliana A, Alina C, Elena CR, Dorin C. Ophthalmological implications of the chronic infections with the hepatitis C Virus. Rom J Ophthalmol 2015; 59:263-268

[117] Lee YH, Ji JD, Yeon JE, Byun KS, Lee CH, Song GG. Cryoglobulinaemia and rheumatic manifestations in patients with hepatitis $C$ virus infection. Ann Rheum Dis 1998;57:728-731. doi: 10.1136/ard.57.12.728.

[118] Guennoc X, Narbonne V, Jousse-Joulin S, Devauchelle-Pensec V, Dougados $M$, Daurès JP, et al. Is screening for hepatitis $B$ and hepatitis $C$ useful in patients with recent-onset polyarthritis? The ESPOIR cohort study. J Rheumatol 2009;36:1407-1413. doi: 10.3899/jrheum.081308.

[119] Patel R, Mikuls TR, Richards JS, Kerr G, Cannon GW, Baker JF. Disease characteristics and treatment patterns in veterans with rheumatoid arthritis and concomitant hepatitis C infection. Arthritis Care Res (Hoboken) 2015; 67:467-474, doi: 10.1002/acr.22463.

[120] Sayiner ZA, Haque U, Malik MU, Gurakar A. Hepatitis C virus infection and its rheumatologic implications. Gastroenterol Hepatol (N Y) 2014;10: 287-293.

[121] Zignego AL, Ramos-Casals M, Ferri C, Saadoun D, Arcaini L, Roccatello D, et al. International therapeutic guidelines for patients with HCV-related extrahepatic disorders. A multidisciplinary expert statement. Autoimmun Rev 2017;16:523-541. doi: 10.1016/j.autrev.2017.03.004.

[122] Dou XG, Bai H. Diagnosis and treatment of chronic hepatitis $C$ with concomitant extrahepatic manifestations deserves a closer look. J Transl Int Med 2017;5:1-3. doi: 10.1515/jtim-2017-0009.

[123] Chien CH, Lin CL, Hu CC, Chang JJ, Chien RN. Clearance of hepatitis C virus improves insulin resistance during and after peginterferon and ribavirin therapy. J Interferon Cytokine Res 2015;35:981-989. doi: 10.1089/jir. 2014.0200.

[124] Younossi ZM, Stepanova M, Afdhal N, Kowdley KV, Zeuzem S, Henry L, et al. Improvement of health-related quality of life and work productivity in chronic hepatitis $C$ patients with early and advanced fibrosis treated with ledipasvir and sofosbuvir. J Hepatol 2015;63:337-345. doi: 10.1016/j. jhep.2015.03.014

[125] Gragnani L, Visentini M, Fognani E, Urraro T, De Santis A, Petraccia L, et al. Prospective study of guideline-tailored therapy with direct-acting antivirals for hepatitis $C$ virus-associated mixed cryoglobulinemia. Hepatology 2016; 64:1473-1482. doi: 10.1002/hep.28753.

[126] Degasperi E, Aghemo A, Colombo M. Treatment of extrahepatic manifestations of hepatitis C virus. Clin Liver Dis 2017;21:631-643. doi: 10.1016/j. cld.2017.03.015.

[127] Sise ME, Bloom AK, Wisocky J, Lin MV, Gustafson JL, Lundquist AL, et al. Treatment of hepatitis $C$ virus-associated mixed cryoglobulinemia with direct-acting antiviral agents. Hepatology 2016;63:408-417. doi: 10. 1002/hep. 28297. 
Kuna L. et al: HCV extrahepatic infections

[128] Arase $Y$, Suzuki F, Suzuki $Y$, Akuta N, Kobayashi M, Kawamura $Y$, et al. Sustained virological response reduces incidence of onset of type 2 diabetes in chronic hepatitis C. Hepatology 2009;49:739-744. doi: 10. 1002/hep. 22703.

[129] Hsu YC, Ho HJ, Huang YT, Wang HH, Wu MS, Lin JT, et al. Association between antiviral treatment and extrahepatic outcomes in patients with hepatitis C virus infection. Gut 2015;64:495-503. doi: 10.1136/gutjnl2014-308163.

[130] Nagao Y, Kimura K, Kawahigashi Y, Sata M. Successful treatment of hepatitis $C$ virus-associated oral lichen planus by interferon-free therapy with direct-acting antivirals. Clin Transl Gastroenterol 2016;7:e179. doi: 10. 1038/ctg.2016.37. 